\title{
SOME ELECTROPHORETIC AND IMMUNOLOGICAL PROPERTIES OF HUMAN SEMEN*
}

\author{
TERRENGE W. MISGHLER AND E. PAUL REINEKE \\ Department of Physiology, Michigan State University, East Lansing, \\ Michigan, U.S.A. \\ (Received 24th May 1965, finalized 13th Fanuary 1966)
}

\begin{abstract}
Summary. Cellulose acetate or disk electrophoresis of human semen and seminal plasma revealed between seven and ten zones of migration, depending on the technique used. Disk electrophoresis of washed human spermatozoa resulted in a pattern of protein separation that could not be distinguished from those obtained by disk electrophoresis of semen or seminal plasma. This is evidence that proteins being removed from spermatozoa are very similar to those present in seminal plasma. Immunological properties of human semen were investigated by immunological double diffusion and immuno-electrophoresis. The latter technique demonstrated at least six antigenic components in semen. These could be resolved into four antigens common with serum and four antigens specific to semen. Immuno-electrophoresis resolved at least ten semen components. These were subdivided into five common to serum and five specific to semen. Finally, there is limited evidence to indicate a substance common between semen and saliva but absent in serum.
\end{abstract}

\section{INTRODUGTION}

The characterization of human semen by its electrophoretic properties was first attempted by Ross, Moore \& Miller (1942), using the Tiselius apparatus. Searcy, Craig \& Bergquist (1964) reported at least eight zones of migration in seminal plasma separated by electrophoresis on cellulose acetate. They also stated that electrophoresis of semen produced essentially the same results. Washed spermatozoa had components with mobilities similar to those of albumin and globulins, plus a stained origin.

The antigenicity of human spermatozoa was first discovered by Landsteiner (1899). Weil, Kotsevalov \& Wilson (1956), using anti-sera to seminal plasma and spermatozoa respectively, could not distinguish between these materials. Weil \& Rodenburg (1960) demonstrated that human spermatozoa acquire antigenicity during passage through the male genital tract. Weil, Herman, Goldberg \& Rodenburg (1960) reported that spermatocoele fluid has four antigenic components, all derived from blood serum, one of which is serum albumin. Stevens \& Fost (1964) reported that antiserum against human

\footnotetext{
* The data reported herein are taken from a thesis presented by the senior author in partial fulfilment of the requirements for the Master of Science degree, College of Natural Science, Michigan State University, 1965.
} 
spermatozoa could be neutralized by the addition of seminal plasma, indicating that all antigens present in spermatozoa are found in seminal plasma. Hermann (1959) reported that immuno-electrophoresis could resolve seminal plasma into at least ten fractions. Klopstock, Haas \& Rimon (1963), using immunoelectrophoresis, presented strong evidence that $\gamma$-globulin is present in human semen.

The purpose of the research reported herein was to investigate more fully the electrophoretic and immunological properties of human semen.

\section{MATERIALS AND METHODS}

The human semen used in this research was procured through a local physician. The semen was approximately $32 \mathrm{hr}$ old when taken to the laboratory and was refrigerated the greater part of this time. Merthiolate $0.01 \%$ (E. Lilly and Co.) was added as preservative.

The antiserum to human serum (anti-human serum) and human semen (anti-human semen) was prepared by the alum precipitation method. Two millimetres of the alum-precipitated protein were injected intramuscularly once a week into the thigh muscle of Dutch black-belted rabbits. The rabbits were bled by cardiac puncture on the 4th week of immunization. The antiserum to human semen was absorbed with equal volumes of human serum. The purpose was to remove antibodies produced against serum proteins present in semen. This is referred to as absorbed anti-human semen.

Cellulose acetate electrophoresis was accomplished using the Shandon Universal Electrophoresis Apparatus (apparatus for cellulose acetate electrophoresis and immuno-electrophoresis was obtained from Colab Laboratories, Inc., Chicago Heights, Illinois, U.S.A.) with the Vokam Power Unit and cellulose acetate strips $2.5 \times 12 \mathrm{~cm}$ in size. A barbitone buffer $(\mathrm{pH} \mathrm{8.6)}$ with calcium lactate was employed. Human serum, semen, seminal plasma, and thrice-washed spermatozoa were subjected to electrophoresis. Five microlitres of a sample were placed on the buffer-impregnated strip one-third the distance from the cathode and a constant current of $1 \mathrm{~mA} /$ strip for $1 \frac{1}{2} \mathrm{hr}$ at room temperature resulted in protein separation. Ponceau $\mathrm{S}(0.2 \%$ in $3 \%$ trichloroacetic acid) was used initially for staining, but was found too insensitive for staining of semen after electrophoresis. Therefore, Nigrosin $(0.001 \%$ in $2 \%$ acetic acid), a more sensitive stain, was employed.

The method of Ornstein \& Davis (1962) was used for disk electrophoresis, the only change being the addition of TEMED $\left\langle\mathrm{N}, \mathrm{N}, \mathrm{N}^{1}, \mathrm{~N}^{1}\right.$, tetramethylenediamine) to the large-pore gel at a concentration of $1 \mu \mathrm{l} / \mathrm{ml}$ to cause faster photopolymerization. The proteins of human serum, semen, seminal plasma and thrice-washed spermatozoa were separated at room temperature with a constant current of $2 \mathrm{~mA} /$ tube for $1 \frac{1}{2} \mathrm{hr}$. Except for spermatozoa, where $0 \cdot 1 \mathrm{ml}$ of packed cells was used, $200 \mu \mathrm{g}$ of protein was mixed with the sample gel in each tube.

Agar gel double diffusion in phosphate buffer at $\mathrm{pH} 7 \cdot 4$, ionicity $0 \cdot 15$ (Ouchterlony 1958), was used to investigate the antigenic properties of human semen. The method of Hirschfeld (1960) was employed for immuno-electrophoresis. 


\section{RESULTS}

The results of electrophoresis on cellulose acetate essentially confirmed those of Searcy et al. (1964) except that no component with a migration similar to that of serum albumin was found in the electrophoresis of washed spermatozoa. Therefore these data will not be presented in detail.

The results of disk electrophoresis of human blood serum, semen and components migrating from washed spermatozoa are shown in Plate 1. Although these figures show the major components in each of the preparations, fractions present in small amounts are not clearly defined because of loss of resolution in photography. Direct examination of the gel columns revealed at least nineteen zones of migration in serum and at least ten in semen and seminal plasma, respectively. It was not possible to distinguish between semen, seminal plasma and washed spermatozoa with regard to their pattern of protein separation. The apparent differences between $b$ and $\mathrm{c}$ in Plate 1 are due to differences in length of the migration path.

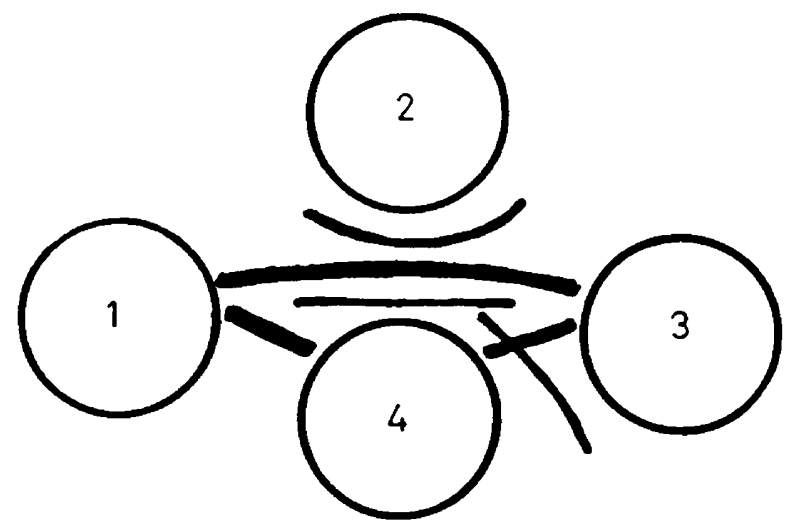

TExT-FIG. 1. The cross-reaction between a component in saliva and anti-human semen absorbed with human serum. 1, Human serum; 2, human semen; 3 , boiled human saliva; 4 , anti-human semen absorbed with human serum. The component in human saliva does not form a line of identity with the semen components.

Immunological double diffusion analysis revealed the following results. Control serum taken from rabbits before injection, when diffused against semen, proved negative. When absorbed anti-human semen was diffused against human serum no precipitation resulted, indicating that absorption of antibodies to serum was complete. When anti-human semen was diffused against human semen at least six antigenic components could be seen. Those which were in common with serum were determined by the diffusion of anti-human serum against semen and this resulted in at least four lines of precipitation. Finally, when absorbed anti-human semen was diffused against semen, at least four precipitin lines specific to semen appeared. Human saliva, either boiled (15 min in a boiling water bath) or untreated, diffused against absorbed anti-semen resulted in a very faint precipitin line. When semen and saliva were compared using absorbed anti-human semen no serological identity resulted between the four visible semen components and the one salivary component (Text-fig. 1).

Immuno-electrophoresis of human semen was accomplished using the three 
afore-mentioned antisera. When anti-human semen was diffused against semen that had been subjected to electrophoresis at least ten lines of precipitation resulted. These are numbered 1 to 10 in order of increasing mobilities (Plate 2a). Anti-human serum was also diffused against semen after electrophoresis to determine which of the ten components were in common with serum (Plate 2b). This resulted in at least five precipitin lines that are given numbers which correspond to similar components in Plate 2(a). Components similar to serum albumin (10), $\gamma$-globulin (1) and other serum globulins $(X, 6,9)$, were revealed. Fraction $X$ did not appear to have a common component in Plate 2(a). The analysis of semen, using absorbed anti-human semen, caused at least five lines of precipitation that appear to correspond to precipitin lines numbered 2, 3 or $4,5,7$ and 8 .

\section{DISCUSSION}

The results of the cellulose acetate electrophoresis confirmed, as already indicated, those obtained by Searcy et al. (1964). The greater sensitivity of Nigrosin as compared to Ponceau S permitted the use of samples only one-fourth the size used in earlier work.

Disk electrophoresis resolved semen and seminal plasma into at least ten components. Electrophoretic components removed from washed spermatozoa are very similar to those present in seminal plasma. Stevens \& Fost (1964) have also reported that spermatozoa have antigenic components in common with seminal plasma. Our results suggest that the proteins removed from spermatozoa could be the spermatozoal coating antigens proposed by Weil et al. (1956), and Weil \& Rodenburg (1960). At the same time, it is possible that the serum proteins found in spermatocoele fluid by Weil et al. (1960) would be attached to spermatozoa and might be removed by electrophoresis. The results presented here, as well as those of others, demonstrate that components found on the spermatozoa would have factors adsorbed from seminal plasma, but the possibility that proteins from within the spermatozoa could contribute to these results cannot be eliminated. Finally, Edwards, Ferguson \& Coombs (1964) and others have demonstrated the presence of fixed $\mathrm{AB}$ blood group antigens on spermatozoa of secretors. So far as the authors are aware, it has not been shown whether or not these antigens will be removed from the spermatozoa by electrophoresis.

The immunological investigation of semen using double diffusion demonstrated the antigenic complexity of this substance. The fact that the six components found in semen could be resolved to four common to serum and four specific for semen supports this conclusion. The possibility arises that there could be present in saliva trace amounts of a heat-stable substance that is common with semen but absent from serum. This is not the $\mathrm{AB}$ blood group substance as it was found in the saliva of a group $O$ individual.

The results of immuno-electrophoretic analysis of human semen confirm reports of others that most of the components are in the $\alpha-2$ and $\beta$ range. The use of antiserum definitely revealed fractions indicative of serum albumin and $\gamma$-globulin as demonstrated by Hermann (1959) and Klopstock et al. (1963) respectively. Disk electrophoresis also produced at least ten fractions. It is 


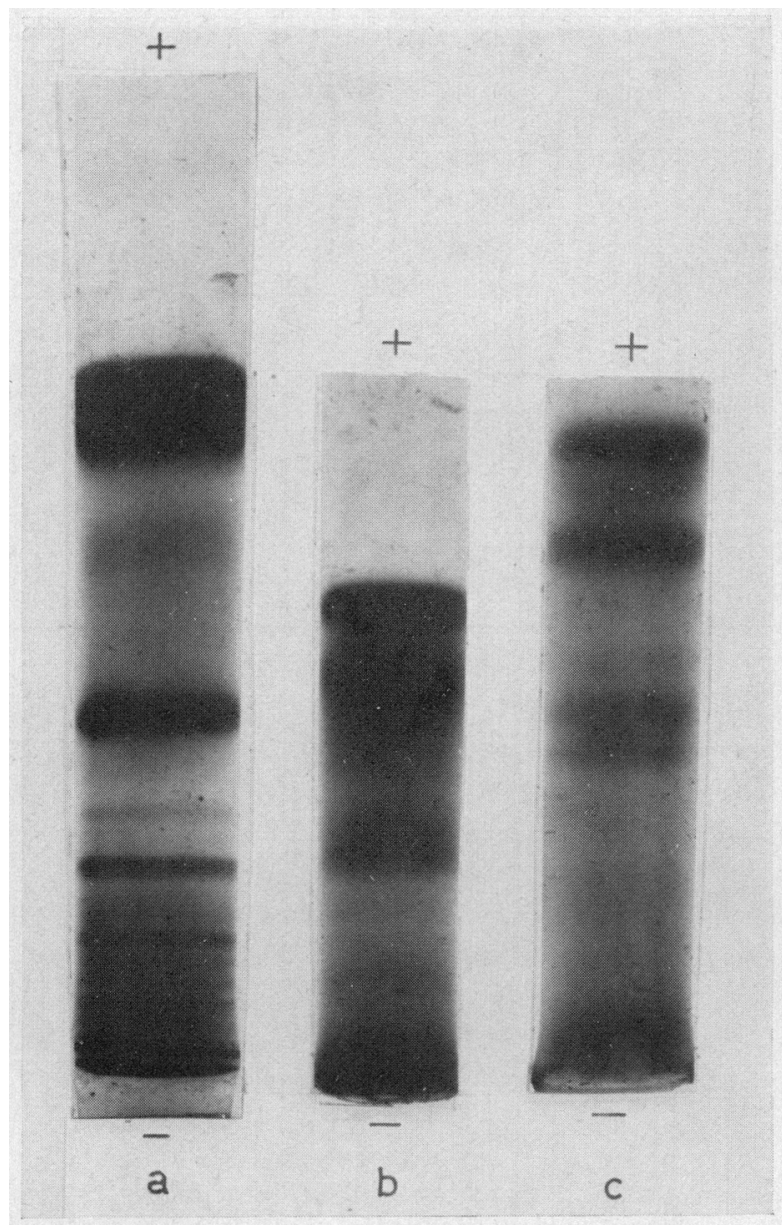

Disk electrophoresis. (a) Human serum, (b) human semen, and (c) washed human spermatozoa. It is difficult to distinguish between the pattern of human semen and washed human spermatozoa. This indicates that the electrophoretic components are similar.

(Facing p. 128) 

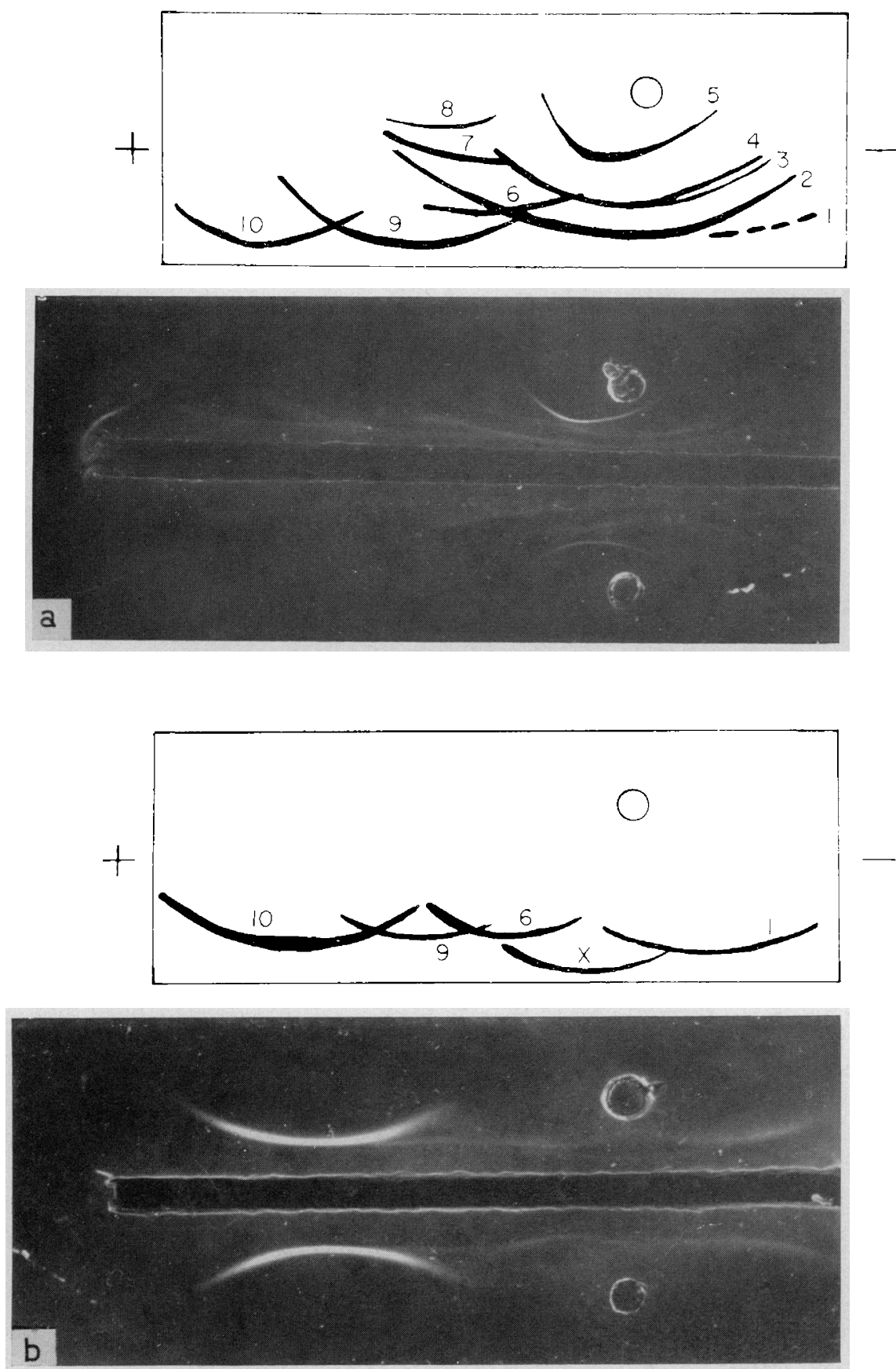

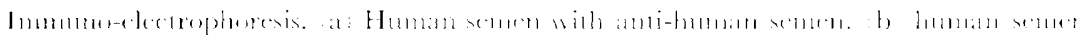

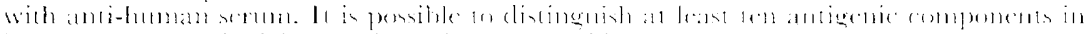

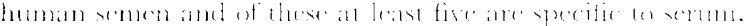


impossible to state that these two techniques resolve the same proteins, because two different criteria are being used to develop and characterize them, but it is probable that these two procedures do resolve the same or similar fractions.

\section{ACKNOWLEDGMENTS}

The authors wish to thank Dr James S. Feurig and Dr Raymond Kinzel for their aid in procuring the human semen. We also thank Dr Lloyd C. Ferguson and Dr Harold Hafs for their advice in the planning of this research.

\section{REFERENCES}

Edwards, R. G., Ferguson, L. C. \& Coombs, R. R. A. (1964) Blood group antigens on human spermatozoa. 7. Reprod. Fert. 7, 153.

Hermann, G. (1959) Immuno-electrophoretic analysis of human sperm plasma. Clin. chim. Acta, 4, 116.

Hirschfeld, J. (1960) Immunoelectrophoresis-Procedure and application to the study of groupspecific variations in sera. Sci. Tools, 7, 18.

Kiopstock, A., HaAs, R. \& Rimon, A. (1963) Immunoelectrophoretic analysis of seminal plasma. Fert. Steril. 14, 530.

LANDSTEINER, K. (1899) Zur Kenntnis der spezifisch auf blutkörperchen workenden Sera. Zentb. Bakt. Parasitkde, 25, 415.

Ornstern, L. \& Davrs, B. J. (1962) Disc electrophoresis. Distillation Products Industries, Rochester, New York.

Ouchterlony, O. (1958) Diffusion-in-gel methods. Prog. Allergy, 5, 1.

Ross, V., Moore, D. H. \& Miller, E. G. (1942) Proteins of human seminal plasma. 7. biol. Chem. 114, 667.

Searcy, R. G., Craig, R. G. \& Bergquist, L. M. (1964) Immunochemical properties of normal and pathologic seminal plasma. Fert. Steril. 15, 1.

Stevens, K. M. \& Fost, C. A. (1964) Sperm and antibody production in rabbits following immunization with sperm and semen. Proc. Soc. exp. Biol. Med. 117, 125.

Weir, A. J., Hermann, J. R., Goldberg, A. S. \& Rodenburg, J. M. (1960) Immunological and chemical studies of spermatocele fluids. F. Urol. 85, 665.

Weir, A. J., Kotsevalov, O. \& Wilson, L. (1956) Antigens of human seminal plasma. Proc. Soc. exp. Biol. Med. 92, 606.

Weir, A. J. \& Rodendurg, J. M. (1960) Immunological differentiation of human testicular (spermatocele) and seminal spermatozoa. Proc. Soc. exp. Biol. Med. 105, 43. 